\title{
Риски распространения в РФ новых вирусных и бактериальных болезней овощных культур через предприятия защищенного грунта
}

\section{А.Н. Игнатов, Г.Г. Челидзе, К.С. Воробьева}

Основные пути проникновения новых видов и форм микроорганизмов на предприятия защищенного грунта - семена и посадочный материал, включая рассаду, произведенную в других предприятиях, готовая продукция из других регионов и стран, складируемая в пределах тепличных хозяйств, вода для полива и приготовления рабочего раствора в гидропонной культуре, и иногда - рабочие в теплицах, контактировавшие с зараженными растениями вне хозяйства. Главная проблема выявления источника заражения - длительный инкубационный период для вирусных и бактериальных болезней и необходимость инструментальных методов (ИФА, ПЦР) идентификации патогена.

Ключевые слова: бактерии, вирусы растений, агроценоз.

П о итогам 2018 года было введено в эксплуатацию около 300 га зимних теплиц, их общая площадь составила порядка 2,5 тыс. га на 10\% больше, чем в 2017 году. По прогнозу Минсельхоза России, в 2019 году отечественные с.-х. организации соберут около 1,3 млн т овощей защищенного грунта [1]. Внедрение многооборотной технологии и интерплантинга [2] позволяет добиться высокой урожайности и стабильной продуктивности тепличных растений.

Но несмотря на это, проблема защиты растений от болезней по-прежнему остается актуальной даже при улучшенной технологии выращивания тепличных культур. В последние годы на территории России из-за нарушения агротехники, отсутствия своевременной и достоверной диагностики фитопатогенных бактерий в посевном материале и на растениях, а также неправильно разработанной системы защитных мер отмечается проявление вредоносности бактериальных и вирусных заболеваний растений.

В современных высокотехнологичных теплицах вирусные и бактериальные болезни заняли первое место, и многократно возросла их вредоносность. А.К. Ахатов и Е.А. Ахатов [3] описали факторы технологии, способствующие распространению этих патогенов:

- сбор продукции с молодых растений (механические повреждения, пе- ренос инфекции в рядах);

- интерплантинг - молодые растения подсаживают среди стареющих для того, чтобы к моменту ликвидации отслуживших растений молодые уже вступили в плодоношение (перенос инфекции со старых растений к молодым);

- короткий разрыв между оборотами (нет времени для дезинфекции и дезинсекции);

- теплица работает практически круглогодично (постоянное накопление инфекции).

Анализ известных случаев появления новых бактериальных и вирусных фитопатогенов в предприятиях защищенного грунта показывает, что основными путями проникновения новых видов и форм микроорганизмов являются семена и посадочный материал, включая рассаду, произведенную в других предприятиях, готовая продукция из других регионов и стран, складируемая в пределах тепличных хозяйств, вода, используемая для полива и приготовления рабочего раствора в гидропонной культуре растений, и иногда - рабочие в теплицах, контактировавшие с зараженными растениями вне хозяйства. Главной проблемой выявления источника заражения является длительный инкубационный период для вирусных и бактериальных болезней и необходимость инструментальных методов (ИФА, ПЦР) идентификации патогена.
Иногда, использование биологических препаратов, произведенных без контроля качества или с истекшим сроком хранения (хранением в неправильных условиях), приводит к усилению заражения культур различными бактериальными и грибными болезнями.

Если по отношению к известным патогенам есть отработанные методы диагностики зараженности растений, семян, воды, и в некоторых случаях - препараты биологической защиты или устойчивые сорта и гибриды, то новые возбудители болезней тепличных растений всегда представляют опасность наивысшего уровня, в первую очередь из-за длительного периода их идентификации.

Бактериальные болезни растений в защищенном грунте

В качестве примера нового заболевания, можно привести бородатость корней овощных культур в защищенном грунте. В 2013-2014 годах в ряде тепличных хозяйств России было отмечено поражение культур огурца и томата, выращиваемых на минеральной вате, заболеванием, сходным с ранее описанным «корневым матом» - «root mat» (синоним: «бешенство корней» - «сrazy roots») [4]. Возбудитель заболевания - Agrobacterium spp. bv1, несущая плазмиду Ri (pRi). Бактерии проникают в растения через ранки на корнях или стеблях. Симптомы заболевания проявляются после переноса в растительную клетку фрагмента плазмидной ДНК (pRi ДНК). Первые признаки болезни замечают примерно через пять недель после заражения. В течение этого времени отмечают активный рост корневой системы, и плотное переплетение корней препятствует проникновению в субстрат питательного раствора и способствует развитию других фитопатогенных бактерий и грибов. Продуктивность культуры при отсутс- 
твии других болезней снижается на 15 - 20\%. Болезнь, впервые появившаяся в Великобритании, к началу 2010-х стала обычной проблемой в Европейском Союзе, Японии, Новой Зеландии, а в России она распространилась на огромной территории в течение одного года после выявления, в первую очередь, благодаря инфицированной рассаде, поставляемой в новые тепличные комбинаты из уже пораженных, зараженным семенам и воде. Благодаря этому, очаги заражения широкого спектра культурных растений распространились далеко за пределы традиционного ареала возбудителя [4].

Другой бактериальный патоген, Ralstonia solanacearum, наиболее известный как возбудитель бурой гнили картофеля и бактериального увядания (южного вилта) томата, стоит практически на пороге отечественной тепличной индустрии (рис. 1). В 1975 году Ralstonia solanacearum была включена в список карантинных объектов Европейской организации защиты растений (список А2 ограниченно распространенные объекты) [5]. При высоких температурах (29-35 $\left.{ }^{\circ} \mathrm{C}\right)$ и влажности бактерии быстро размножаются, и болезнь может уничтожить растение за несколько дней. При более низких температуpax $\left(22-25^{\circ} \mathrm{C}\right)$ растения могут сохранять латентную инфекцию месяцами. В августе 2015 года $R$. solanacearum (раса 1, позднее определенная как R. pseudosolanacearum) была обнаружена в теплице в Нидерландах, на растениях антуриума на срезку (Anthurium spp.). В 2015 и 2016 годах патоген был выявлен в пятнадцати компаниях, выращивавших де- коративные культуры, в том числе в пяти питомниках. Согласно последним данным национальной службы защиты растений, $R$. solanacearum присутствует в Нидерландах в производстве картофеля, в окружающей среде (поверхностные воды) [6]. В последующем $R$. solanacearum на растениях розы была выявлена на территории Польши (осень 2016 года), Португалии (2016-2017 годы), Швейцарии [6]. В 2016 и 2017 годах Ralstonia solanacearum была выявлена массово в промышленных посадках голубики (Vaccinium corymbosum) [7]. Есть сообщение о выделении бактерий рода Ralstonia из растений сирени в 2016 году в РФ [8].

Таким образом, интродукция $R$. solanacearum в новые регионы может произойти не только с семенным и продовольственным картофелем, зараженным бактериальной инфекцией в латентном состоянии, но и с саженцами розы, пеларгонии, голубики, сирени и других декоративных культур, выращиваемых в защищенном грунте, не говоря уже о растениях томата. При естественном распространении патогена источниками болезни становятся инфицированная почва, зараженные растительные остатки, сорняки из семейства пасленовых и крапива, поливная вода. Патоген также может распространяться нематодами и другими переносчиками (насекомыми, клещами).

$R$. solanacearum (все группы вида) входит в список А1 карантинных объектов в РФ, и о факте обнаружения этого патогена должно сообщаться в службу Россельхознадзора.

Декоративные и ягодные культуры, размножаемые в теплицах, могут также быть поражены другим карантинным объектом - Xylella fastidiosa [9]. Этот патоген в основном вредоносен для древесных и кустарниковых культур, но также может поражать и однолетние растения из семейств пасленовые и сложноцветные. Карантинный патоген со сходным циклом развития - Liberibacter psyllaurous (syn. L. solanacearum) также распространяется на томате в условиях теплиц [10] благодаря насекомым-переносчикам.

Новые возбудители мокрой гнили корня и плодов, водянистой гнили стебля - фитопатогенные энтеробактерии Pectobacterium carotovorum subsp. brasiliense, $P$. wasabiae, Dickeya dianthicola, D. dadantii и $D$. solani уже присутствуют в РФ на картофеле и овощных культурах. Для этих видов характерно заражение насекомыми, через поливную воду, почву либо тепличный субстрат [11]. Их распространение было тесно связано с импортом овощной продукции и семенного картофеля из стран субтропического климата в 20092015 годах. Возбудитель бактериального рака томата - Clavibacter michiganensis subsp. michiganensis, хотя и входит в число карантинных объектов, ограниченно распространенных в Европейском Союзе (А2) [12], встречается во всех основных зонах выращивания томата в РФ, в первую очередь, благодаря семенной инфекции. В последние годы обнаружено, что картофельная раса этого патогена способна поражать томат, картофель, а также, в незначительной степени перец сладкий. Родственный патоген - Clavibacter michiganensis subsp. sepedonicus

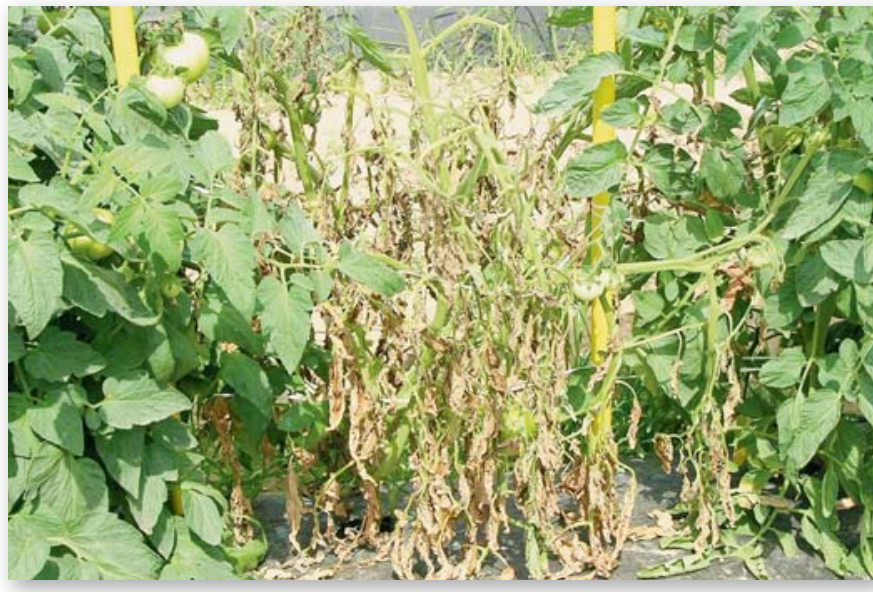

Рис. 1. Южный вилт томата (Solanum lycopersicum L.) вызываемый Ralstonia solanacearum. Фотография публикуется с разрешения автора (Don Ferrin, Louisiana State University Agricultural Center, Bugwood.org)

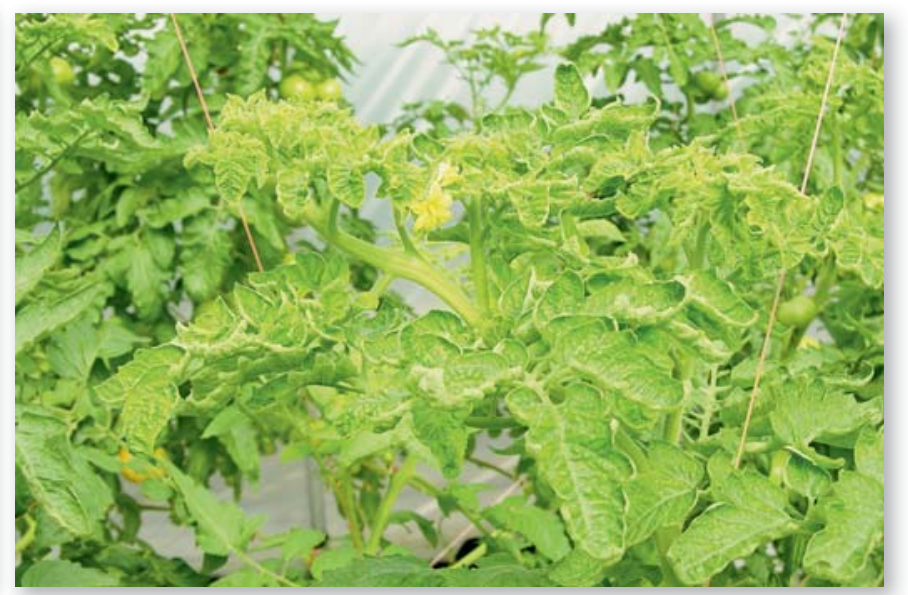

Рис. 2. Симптомы, вызываемые бегомовирусом желтой курчавости листьев томата (Begomovirus TYLCV) Фотография публикуется с разрешения автора (Don Ferrin, Louisiana State University Agricultural Center, Bugwood.org) 
(возбудитель кольцевой гнили картофеля), также способен поражать томат в теплицах, и учитывая широкое распространение и соседство участков под картофелем с тепличными комбинатами, они могут взаимно служить источниками заражения друг для друга [11].

\section{Вирусные болезни в теплицах}

Число видов вирусов, поражающих наиболее важные культуры в закрытом грунте, исчисляется десятками. Теоретически инструментальными методами возможно определять все присутствующие в растении вирусы, но по экономическим причинам, сейчас проводят ПЦР или иммунологический анализ только для наиболее вредоносных видов.

На проявление симптомов, динамику развития и вредоносность вирусных болезней влияет комплекс факторов: возраст растений, их генетические особенности и, особенно, условия выращивания (диапазон температур). Наличие других вирусов в растении может полностью изменить симптомы болезни и усилить их вредоносность во много раз. Необходимо учитывать и то, что несмотря на видоспецифичные названия вирусов, они способны заражать многие виды растений различных семейств, нередко развиваясь в них без проявления внешних симптомов болезни (т.н. латентное заражение) [13].

Симптомы разных вирусных болезней часто сходны, и трудность их визуальной диагностики связана с тем, что они напоминают симптомы бактериальных, фитоплазменных заболеваний или физиологических нарушений. Предварительный диагноз обязательно подтверждается инструментальными методами, например, методом ПЦР (полимеразная цепная реакция) или ИФА (иммуноферментный анализ).

Среди вирусов с максимальным потенциальным риском - бегомовирус желтой курчавости листьев томата (Tomato yellow leaf curl begomovirus TYLCV). Главным растением-хозяином вируса является томат и другие пасленовые, но он также поражает растения семейств тыквенные и бобовые. Вирус переноситься табачной (синоним: хлопковой) белокрылкой (лат. Bemisia tabaci). Этот переносчик отмечен в Крыму и на Черноморском побережье РФ. Растения томата, заразившиеся в молодом возрасте, останавливаются в росте и не образуют плодов. Следующие листья хлоротичные, с деформированными пластинками, закрученными вверх краями и искривлениями между жилками [14] (рис. 2).

Другой опасный вирус, недавно проникший в тепличные хозяйства Северной Европы - потивирус желтой мозаики цукини (Zucchini yellow mosaic virus, ZYMV) [14]. Он вызывает симптомы резкой мозаики; иногда с симптомами шнуровидности. Заражение на ранних стадиях вегетации может вызывать задержку в развитии растений (карликовость), неравномерную окраску и уродливость плодов, переноситься неперсистентным способом несколькими видами тлей и механическим путем. Особенностью групп Бегомо- и Поти-вирусов является быстрая адаптация к новым растениям-хозяевам.

Среди наиболее опасных возбудителей защищенного грунта - вирус обыкновенной мозаики огурца (Cucumber mosaic virus (CMV)), или BOM-1, вирус зеленой крапчатой мозаики огурца (Cucumber green mottle mosaic tobamovirus (CGMMV)), или ВОМ-2, и вирус мозаики пепино на томате (Pepino mosaic potexvirus, или PepMV) [3, 11]. CMV способен поражать более 775 видов растений. В теплицах вирус встречается практически повсеместно, попадает туда с переносчиками или с сорняками. Есть сведения об обнаружении вируса в семенах огурца, хотя патоген переносится в основном тлями и другими сосущими вредителями. Вирус CGMMV поражает растения в теплицах, вредоносность максимальна при заражении молодых растений, завязавшиеся зеленцы становятся крапчатыми, невкусными, иногда и с горьковатым привкусом. Источники инфекции - обычно семена, растительные остатки и почва, отмечено распространение патогена с поливным раствором [11]. РерMV был зарегистрирован в России в 2012 году, хотя, возможно, первые очаги встречались еще в 2007-2008 годах $[11,15]$. Источником вируса стали, скорее всего, семена томата. Переносчиками вируса могут быть шмели, клопы-слепняки, тли и четырехногие клещи, но чаще - персонал в процессе ухода за растениями. Бронзовость, или пятнистое увядание томата (Tomato spotted wilt virus (TSWV)) распространено практически повсеместно. В зимних теплицах заболевание встречалось редко, но в последнее время его ежегодно отмечают на томате на юге России. В 2012 году вирус был обнаружен в теплицах Подмосковья [15].
В России климатические условия всегда служили важным фактором снижения вредоносности вирусных и бактериальных болезней растений. Популяции большинства фитопатогеннных бактерий и вирусов в агроценозах, переносчиках и многолетних растениях резко снижались в зимний период, и их медленное восстановление весной и в начале лета приводило к низкой пораженности рано созревающих сортов различных культур, а при неблагоприятных условиях заболевания не проявлялись вообще. Распространение тепличных комбинатов с гидропонной технологией привело к появлению круглогодично работающих потенциальных очагов вирусного и бактериального заражения для многих теплолюбивых патогенов и их переносчиков, потому что ни дренажные стоки, ни растительные отходы производства обычно не обеззараживаются. Следует вести постоянно работу по мониторингу и предотвращать распространение новых фитопатогенов в предприятиях защищенного грунта. Из-за особенностей этих возбудителей, профилактические мероприятия и использование устойчивых сортов являются практически единственными действенными мерами снижения потерь урожая.

\section{Библиографический список}

1.Пресслужба Минсельхоза РФ, 2019. [Электронный pecypc]. URL: http://mcx.ru/press-service/news/v-2019godu-urozhay-teplichnykh-ovoshchey-prognoziruetsyana-urovne-1-3-mln-tonn/ Дата обращения: 15.03.2019. 2.Гришечкина Л.Д. Проблемы защиты овощных культур от болезней в теплицах // Защита и карантин растений. 2011. № 2. С. 16-18.

3.Ахатов А.К., Ахатов Е.А. Наиболее вредоносные болезни овощных культур в современных тепличных комбинатах // Гавриш. 2014. № 3. С. 16-23.

4.Ходыкина М.В. и др. Новая бактериальная болезнь тепличного огурца // Гавриш. 2014. №3. С. 24-29.

5.Anonymous. OEPP/EPPO (2004) PM 7/21: Ralstonia solanacearum. Diagnostic protocols for regulated pests.

6.Anonymous. EPPO Reporting Service no. 09 - 2017, Num. article: 2017/172

7.Harmon P.F. and Bayo D. Getting to the Bottom of Bacterial Wilt in Blueberries. URL: https://www. growingproduce.com/author/deanna-bayo/ September 20, 2017. Дата обращения 15.03.2019.

8.Выделение и идентификация культивируемых эндофитных микроорганизмов из побегов Syringa vulgaris L. / А.А. Криницына, А.С. Сперанская, О.А. Чурикова, М.А. Егорова, М.Р. Леонтьева, Е.А.Цавкелова // Мониторинг и биологические методы контроля вредителей и патогенов древесных растений: от теории к практике. Материалы Всероссийской конференции с международным участием. Москва, 18-22 апреля 2016 г. ИЛ СО РАН. Красноярск, 2016. С. 109-110.

9. Oliver J.E., Cobine P.A., De La Fuente L. Xylella fastidiosa isolates from both subsp. multiplex and fastidiosa cause disease on southern highbush blueberry (Vaccinium sp.) under greenhouse conditions // Phytopathology. 2015. V. 105. No. 7. P. $855-862$

10.Brown J.K. et al. First report of "Candidatus Liberibacter psyllaurous"(synonym "Ca. L. solanacearum") 
associated with 'tomato vein-greening'and 'tomato psyllid yellows' diseases in commercial greenhouses in Arizona // Plant Disease, 2010. V. 94. N. 3. P. 376-376.

11.Ахатов А.К. и др. Болезни и вредители овощных культур и картофеля. М.: КМК, 2013. 463 с.

12.Anonymous. PM 7/42 (3) Clavibacter michiganensis subsp. michiganensis Bulletin OEPP/EPPO Bulletin. 2016 V. 46. No. 2. P. $202-225$.

13. Hadidi A., Khetarpal R.K., Koganezawa H. Plantvirus disease control // The American Phytopathological Society. Minnesota, 1998. 684 p.

14.Lemmetty A., Laamanen J., Soukainen M. Emerging virus and viroid pathogen species identified for the first time in horticultural plants in Finland in 1997-2010 // Agricultural and Food Science. 2011. V. 20. No. 1. C. 29-41.

15.Ха Тхи Куинь Чанг. Распространение и патогенез вирусных заболеваний томата в условиях Вьетнама и России: автореф. дисс. ... канд. биол. наук. М., 2013. 20 с.

\section{Об авторах}

Игнатов Александр Николаевич, (ответственный за переписку), доктор биол. наук, зам. ген. директора по научной работе, ООО «Исследовательский Центр «ФитоИнженерия».

E-mail: an.ignatov@gmail.com

Челидзе Георгий Гарриевич, специалист, ООО «Исследовательский Центр «ФитоИнженерия».

E-mail: winnyduff@gmail.com

Воробьева Ксения Сергеевна, специалист, ООО «Исследовательский Центр «ФитоИнженерия».

E-mail:i.evsevia@gmail.com

Risks of spreading of new viral and bacterial diseases of vegetable crops in the Russian Federation through greenhouse production

A.N. Ignatov (author for correspondence), DSc, deputy general director for research work, Research Center "PhytoEngineering". E-mail: an.ignatov@gmail.com

G.G. Chelidze, specialist, Research Center «Phytoengineering».

E-mail: winnyduff@gmail.com

K.S. Vorobyova, specialist, Research

Center «PhytoEngineering".

E-mail:i.evsevia@gmail.com

Summary. Seeds, planting material, including seedlings produced in other greenhouses, warehouse products from other regions and countries, stored within greenhouses facilities, water used for irrigation and preparation of working solution in hydroponic plant culture, and sometimes - workers in greenhouses with direct contact with infected plants outside the greenhouses were the main ways of introduction of new plant diseases. A long incubation period for viruses and bacterial diseases, instrumental methods (ELISA, PCR) needed to identify the pathogen are the main problems of correct identification for the source of infection.

Keywords: bacteria, viruses of plants, agrocenosis.

\section{Татьяна Александровна Дементьева}

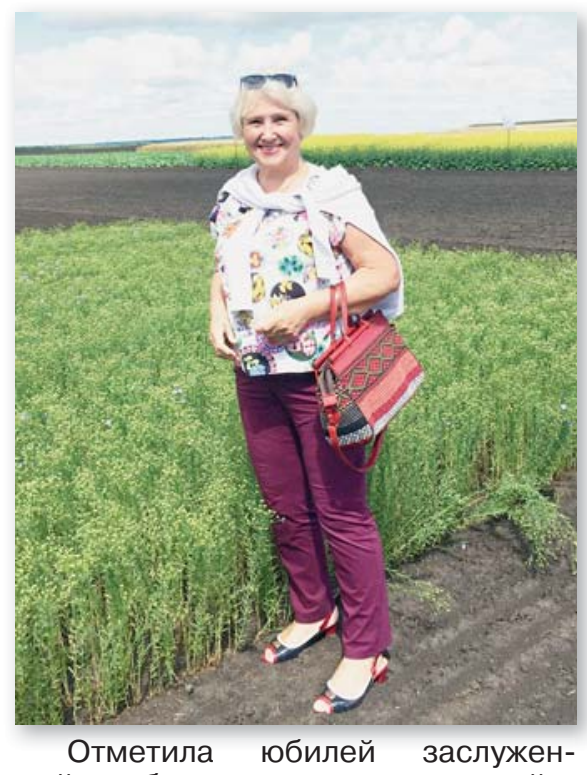
ный работник сельского хозяйства Московской области Татьяна Александровна Дементьева.

Татьяна Александровна родилась в станице Медведовская Краснодарского края и была седьмым ребенком в семье. В 1967 году она окончила Брюховецкий совхоз-техникум и до 1970 года работала в Кустанайской области Казахстана в должности агронома. После юбиляр девять лет работала на Грибовской овощной станции (ныне ФГБНУ ФНЦО) и параллельно получила высшее образование в ВСХИЗО (сейчас РГАЗУ). С 1979 года она бессменно работает в Московском филиале «Госсорткомиссия». Более пятидесяти лет она посвятила сельскому хозяйству, из них почти 40 лет - сортоиспытанию. По сей день Татьяна Александровна самоотверженно трудится, занимаясь любимым делом и передавая свой опыт молодому поколению.

Коллектив ФГБУ «Госсорткомиссия", Московского филиала «Госсорткомиссия", Агрохолдинга «Поиск", редакция журнала «Картофель и овощи» сердечно поздравляют Татьяну Александровну с юбилеем, желают ей крепкого здоровья, долгих лет жизни, благополучия, семейного счастья и творческих успехов!

\section{Григорий Фёдорович Монахос}

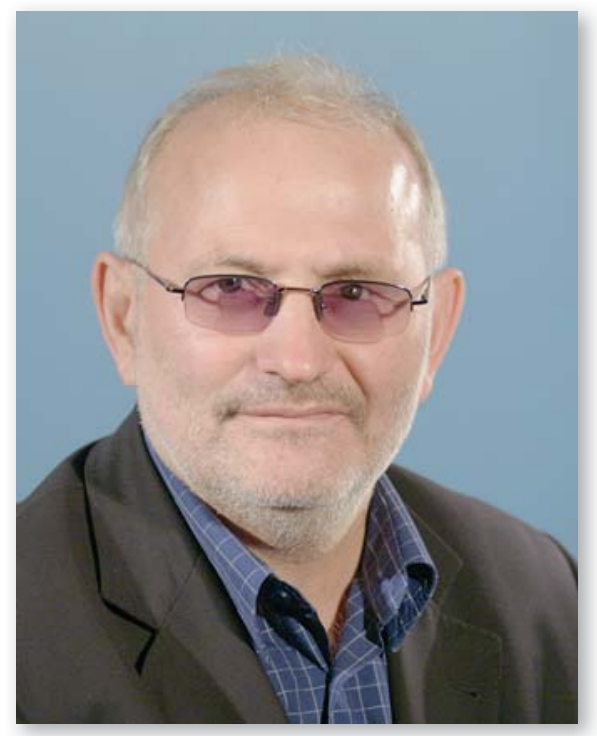

Исполнилось 65 лет выдающемуся селекционеру, канд. с.- х. наук, директору Селекционной станции имени Н.Н.Тимофеева Григорию Фёдоровичу Монахосу.

Юбиляр - автор и соавтор более 50 гибридов овощных культур. Созданные им гибриды белокочанной капусты Орион, Колобок, Валентина, Доминанта, Престиж и Триумф превосходят зарубежные и отечественные сорта по лежкоспособности в 1,51,8 раза. Талантливому селекционеру удалось сделать невообразимое - создать капусту с групповой устойчивостью к трем самым вредоносным заболеваниям: киле капустных, сосудистому бактериозу и фузариозному увяданию. Его гибриды выращивают по всей России, в Киргизии, Казахстане, Украине и Беларуси. Григорий Фёдорович - талантливый человек и исследователь. Ему присущи постоянный творческий поиск, совершенствование и разработка новых методов, комплексный подход. Он - чуткий руководитель, интересный собеседник, пример трудолюбия и верности делу для коллег и учеников.

Коллективы Селекционной станции имени Н.Н. Тимофеева, Агрохолдинга «Поиск", сотрудники РГАУ-МСХА имени К.А. Тимирязева, селекционеры России, редакция журнала «Картофель и овощи" сердечно поздравляют Григория Фёдоровича с юбилеем и от души желают крепкого здоровья, творческого долголетия и личного благополучия. 